\title{
Relationship between Adversity Quotient and Academic Problems among Student Teachers
}

\author{
Dr Usha Parvathy ${ }^{1}$, Praseeda M. ${ }^{2}$ \\ (Associate Professor, Avila College of Education, Cochin, PIN 682010, Kerala, India) \\ (Higher Secondary School Teacher, Palakkad, Kerala, India)
}

\begin{abstract}
Adversity quotient is the capacity to adjust with the adversities in life. A person with good Adversity quotient can achieve the goal by fighting against all odds. It is also related to many other factors like self esteem, motivation, fighting spirit, creativity, sincerity, positive attitude, optimism, emotional stability etc. Adversity quotient is also related to the Academic problems of students. This study is conducted to find out the level of academic problems and adversity quotient among student teachers. The study also analyses the relationship between adversity quotient and academic problems among student teachers. A teacher can transfer his/her ability to the next generation and inculcate such qualities in the students. The method used was survey and the sample was a random sample of 300 student teachers from Kerala state in India. The value of correlation co-efficient obtained for adversity quotient and academic problems $(r=-0.52$, significant at 0,01 level) shows that the two variables are closely related.
\end{abstract}

Keywords: Academic problems, Adversity quotient, Self esteem. Student teachers.

\section{Introduction}

Teacher education is an important area in the field of education as the future of any country The syllabus and curriculum of Degree and Diploma courses in Education are designed to produce professionally competent teachers. In order to face challenges and to fulfill the goals of education a well designed programme of professional education is required for the prospective teachers. Teacher education programme is the programme for professional preparation of teachers and the students undergoing this course are called student teachers. The aim of the course is to give professional training and knowledge to students and to instill necessary values and skills. Bachelor of Education (B. Ed) is a course offered for those interested in pursuing career in teaching. B. Ed is an undergraduate academic degree which qualifies the graduate in any degree as a teacher in the school. B. Ed is a course leading to the bachelors' degree in education. The course extends for a period of one year with two semesters. It is a time bound course with records, projects, practicum etc. National Council for Teacher Education is the statutory body which regulates courses in teaching in India.

Most of the student teachers are frustrated during the B. Ed course and this will affect their achievement also. The academic problems may affect the future career of student teachers. This research work studies the academic problems faced by student teachers during the period of B. Ed course and its relationship with the adversity quotient.

Adversity quotient is the capacity to deal with the adversities of his/her life. As such it is the science of human resilience. It tells how well one withstands adversity and his/her ability to triumph over it. By understanding the concept we can better understand how we and others react to challenges and adversities in all aspects of our lives. It measures our ability to face the adversities. It includes various components such as performance, motivation, empowerment, creativity, productivity, learning etc. It provides the tools for improving how you respond and thus overall professional effectiveness. (www.peaklearning.com.)

Adversity quotient also plays a very important role in one's life. Students face a lot of situations or challenges in their daily life. To overcome or to face these problems, adversity quotient is required. A person who has the capacity to face and overcome the adversities can attain his/her goals in life easily. A person should have the ability to respond to a particular adversity situation in an amicable way. This ability is essential for student teachers to solve their day to day problems.

Adversity quotient is also related to self esteem. Self esteem is a concept that refers to a person's overall evaluation of himself. It is an appraisal of one's own worth. It is the opinion one has about him. (depression.about.com/od/glossarys/a/self-esteem.htm)

A study conducted by Ao Jie,Deng Zhi-wen,WuLi-cun ,2009[1] shows that Adversity quotient (AQ) and self-supervision ability of freshmen relates to their studying qualities and mental health. Investigation of 1195 freshmen with the "Adversity Response Profile" and "Self-monitoring Scale "showed that: Freshmen's AQ is generally high, and it suggests that freshmen can overcome general difficulty and adapt to social life; But they have not enough master power to dealing with adversity; Demographic factors such as sex, age etc do not 
significantly influence on AQ of freshman in statistics. Universities should carry out setback education purposefully to improve mental health of undergraduates.

Adversity quotient education is of great importance to success. Psychologically and sociologically, it is significant especially to the contemporary college students. Considering the current situation in adversity quotient education of college students and the actual and the social circumstances of the university, measures should be taken to promote the development of the adversity quotient education. For example, ideas of psychological counseling should be straightened out, psychological instruction organizations should set up courses in education, monitoring of psychology tests should be tightened up, practical training should be carried out, and teachers' value guidance and the students' self-construction need to be emphasized. (Ren Ze-zhong,Pan Hong-jun ,2008) [2]

Mittal (2011) [3] investigated the emotional intelligence of teacher trainees in relation to anxiety. The results revealed that there is a significant relationship exists between emotional intelligence and anxiety of teacher trainees and also concluded that there is a significant difference in the emotional intelligence of teacher trainees belonging to high and low levels of anxiety. Vibhavari \& Uplane (2011) [4] had conducted a study on adversity quotient among secondary school students. They found that in the selected sample most of the students are from families with good socio-economic background. The adversity quotient level of students who performed very well in the academics is found to be below world average.

This study is conducted to find out the level of academic problems and adversity quotient among student teachers. The study analyses the relationship between adversity quotient and academic problems among student teachers. This paper also studies the relationship between adversity quotient and academic problems among student teachers by eliminating the effect of self concept of student teachers.

\subsection{Method}

\section{Methodology}

The main objective of the study was to find out the relationship between Adversity quotient and academic problems among student teachers. Normative survey method was used for this study.

\subsection{Tools}

The tools used for this study was a questionnaire to check the academic problems of student teachers, a rating scale to rate self esteem and an inventory to check the adversity quotient. All the tools were prepared by the investigators.

A compulsory choice inventory was prepared by the investigator to measure the adversity quotient of student teachers. The inventory has 24 items which were based on 24 adverse situations and three options were given for each situation. The response to each adverse situation is marked in the column provided. Among the three options, there is one positive option and two negative options. The positive option carries one mark and no marks were awarded to other two options. A questionnaire was prepared by the investigators to find out the academic problems faced by the student teachers. This questionnaire contains 25 statements. Two options (Yes and No) were given for each statement. The rating scale to rate the self esteem of student teachers contains 40 statements. It is a three point scale. The three choices given for each statement are agree, undecided and disagree. Two marks will be given for agree, one mark for undecided and no marks for disagree. All 40 statements are based on the self concept of an individual The face validity and content validity of all the tools were established. The reliability of all the three tools were found out using test-retest method and the reliability co-efficient of inventory to measure the adversity quotient of student teachers, questionnaire to find out the academic problems faced by the student teachers and the rating scale to rate self esteem of the student teachers were $0.59,0.75$ and 0.65 respectively.

\subsection{Sample}

\subsection{Statistics}

A sample of 300 student teachers from Kerala state in India was selected randomly for the study.

The statistics used for this study was percentage analysis, Karl Pearson's product moment correlation and partial correlation. Karl Pearson's product moment correlation was used to find out the relationship between academic problems and adversity quotient. Partial correlation was used to find out the relationship between academic problems and adversity quotient by excluding the effect of another variable self esteem which is proved to be related to adversity quotient. The equations used are given below:

$\mathrm{r}($ Co-efficient of correlation $)=\mathrm{N} \sum \mathrm{XY}-\sum \mathrm{X} \sum \mathrm{Y}$

$\mathrm{XY}=$ Sum of the products of each $\mathrm{X}$ score multiplied with its corresponding $\mathrm{Y}$ score. 
$\mathrm{N}=$ total number of cases or scores

$\mathrm{X}^{2}$ and $\mathrm{Y}^{2}=$ square of $\mathrm{X}$ and $\mathrm{Y}$ scores.

The formula for calculating first order partial correlation is as follows.

$$
r \quad 12.3=\frac{r_{12}-r_{13}-r_{23}}{1-r_{13}^{2} \times 1-r^{2}{ }^{2}}
$$

$\mathrm{r}_{12}=$ correlation between $\mathrm{X}_{1}$ and $\mathrm{X}_{2}$

$r_{13}=$ correlation between $X_{1}$ and $X_{3}$

$r_{23}=$ correlation between $X_{2}$ and $X_{3}$

(Garret, 2005) [5]

\section{Objectives Of The Study}

- To find out the level of academic problems among student teachers.

- To find out the level of adversity quotient among student teachers.

- To find out the relationship between adversity quotient and academic problems among student teachers.

- To find out the relationship between academic problems and adversity quotient with the effect of self esteem partialled out among student teachers

\section{Hypotheses Of The Study}

- There is a significant relationship between adversity quotient and academic problems among student teachers.

- There is a significant relationship between academic problems and adversity quotient with the effect of self esteem partialled out among student teachers.

\section{Analysis And Interpretation Of The Data}

- When the scores regarding the Academic problems of student teachers were analysed, $15.67 \%$ of the student teachers belonged to above average category, $62.33 \%$ belonged to average category and $22 \%$ belonged to below average category.

- When the scores regarding the adversity quotient of student teachers were analysed, $21 \%$ of the student teachers belonged to above average category, $61.33 \%$ belonged to average category and $17.67 \%$ belonged to below average category.

- The relationship between adversity quotient and academic problems among student teachers was analyzed using Karl Pearson's product moment correlation and the details are given in Table No -1 .

Table No - 1

\begin{tabular}{|l|l|l|l|l|}
\hline VARIABLES & MEAN & $\begin{array}{l}\text { STANDARD } \\
\text { DEVIATION }\end{array}$ & $\begin{array}{l}\text { PARTIAL } \\
\text { CORRELATION }\end{array}$ & $\begin{array}{l}\text { SIGNIFICANCE } \\
\text { LEVEL }\end{array}$ \\
\hline Academic Problem & 11.71 & 4.88 & \multirow{2}{*}{-0.52} & $\mathrm{p}<0.01$ \\
\hline Adversity Quotient & 15.11 & 5.90 & -0.1 & \\
\hline
\end{tabular}

The correlation co-efficient obtained for these two variables was -0.52 . This shows a significant, negative, substantial correlation between these two variables. The value of $r$ was significant at .01 level. There is a substantial correlation between academic problem and adversity quotient that is if the adversity quotient is high, we can reduce the academic problem to some extent.

- To analyze the relationship between academic problems and adversity quotient with the effect of self esteem partialled out among student teachers in Kerala, the investigator used partial correlation. Table No - 2 gives the details.

\begin{tabular}{|l|l|l|l|l|}
\hline VARIABLES & MEAN & $\begin{array}{l}\text { STANDARD } \\
\text { DEVIATION }\end{array}$ & $\begin{array}{l}\text { PARTIAL } \\
\text { CORRELATION }\end{array}$ & $\begin{array}{l}\text { SIGNIFICANCE } \\
\text { LEVEL }\end{array}$ \\
\hline Academic problem & 11.71 & 4.88 & & \\
\cline { 1 - 3 } Self esteem & 15.11 & 9.20 & & \\
\cline { 1 - 3 } & 65.19 & 5.90 & -0.511 & $\mathrm{p}<0.01$ \\
\hline
\end{tabular}

When the relationship between academic problems and adversity quotient with the effect of self esteem partialled out among student teachers in Kerala was analysed, the correlation co-efficient obtained was -.511. It shows a significant, substantial, negative relationship between academic problems and adversity quotient with the effect of self esteem partialled out. The value obtained is significant at.01 level. 


\section{Conclusions Of The Study}

- There is a significant, negative, substantial correlation between academic problems and adversity quotient among student teachers in Kerala. $(r=-0.52$, significant at 0.01 level)

- There is a significant, substantial, negative relationship between academic problems and adversity quotient with the effect of self esteem partialled out among student teachers in Kerala. $\quad(r=-0.511$, significant at 0.01 level)

A student teacher must have the ability to overcome the adversities in his/her life. By developing this habit we can understand how we and others react to challenges and adversities of our lives. It measures our ability to face the adversities. A person with good adversity quotient will also have qualities like self esteem, motivation, fighting spirit, creativity, sincerity, positive attitude, optimism, good emotional health etc. Any person who has adversity quotient can influence others easily and can help others to overcome hurdles in life. The value of correlation co-efficient obtained for adversity quotient and academic problems $(\mathrm{r}=-0.52$, significant at 0,01 level) shows that the two variables are closely related. A person having the ability to overcome the adversities can easily solve or face any problem. It is to be noted that even after removing the influence of the variable self esteem which is proved to be related to adversity quotient, there is a significant, substantial, negative relationship between academic problems and adversity quotient. When the score of adversity quotient is high, the score regarding academic problems is less among the students. The relationship between these variables may be the same for students doing different courses and also for other people.

A student teacher can transfer his/her ability to the next generation and inculcate such qualities in students. Everyone should have the ability to face the challenges and adversities in his/her life. To improve the adversity quotient, a person should have empathy, sympathy and an ability to understand other's problems. $\mathrm{He} / \mathrm{she}$ should understand the basic cause of problems and find ways to tackle the problems. We have to develop this quality among our students through programmes which create proper awareness among students which in turn will help to create a better society

\section{Acknowledgements}

[1] Ao Jie,Deng Zhi-wen,WuLi-cun (2009). On the adversity quotient of freshmen and tactics of setback education. Retrieved from http://en.cnki.com.cn/

[2] Ren Ze-zhong,Pan Hong-jun (2008). Adversity Quotient Education and the Improvement of Education and Management of College Students. Retrieved from http://en.cnki.com.cn/Article.

[3] Mittal, K., Emotional intelligence of teacher trainees in relation to anxiety. New Frontiers in Education, 44(3), 2011, 311-15.

[4] Vibhavari, B. N.and Uplane, M. M., A study on adversity quotient among secondary school students. Edutracks, 10(6), 2011, 4143.

[5] Garrett, H. E., Statistics in psychology and education (New Delhi: Paragon international publishers, 2005). 